\title{
Interest in Dialogic and Non-Dialogic Teacher Talk Situations in Middle School Science Classroom
}

\author{
Kalle Juuti ${ }^{1}$ (D) Anni Loukomies ${ }^{2,3}$. Jari Lavonen ${ }^{1,3}$
}

Received: 20 March 2019 / Accepted: 18 October 2019 / Published online: 26 November 2019

(C) The Author(s) 2019

\begin{abstract}
Previous research has shown that dialogic teacher talk not only supports students' understanding but also raises their interest. However, there is little, if any, research on the connection between dialogic talk and student interest in classroom situations. To investigate this connection, we collected video observations and experience sampling data. In total, 87 middle school students aged 14 to 16 participated in the study. Data were collected from the classes of six science teachers, and three lessons were video recorded in each teacher's classroom. During the lessons, students were asked several times to express their interest in the situation through the experience sampling method (ESM). The measurements took place in situations where the teacher either talked with the students or talked to the whole group of students. The talk situations were categorised as dialogic or non-dialogic, based on the video recording. On a five-point scale of interest, the median value was 3.3 in non-dialogic talk situations and 3.5 in dialogic talk situations. We hypothesised that students' interest would be higher in dialogic talk situations than in non-dialogic talk situations. The hypothesis was tested with a related samples Wilcoxon signed rank test, and the results supported the hypothesis $(Z=-2.62 ; p<0.05)$. The results suggest that dialogic talk may trigger students' interest in science learning.
\end{abstract}

Keywords Dialogic talk $\cdot$ Experience sampling $\cdot$ Interest $\cdot$ Situation $\cdot$ Middle school

Kalle Juuti

kalle.juuti@helsinki.fi

Anni Loukomies

anni.loukomies@helsinki.fi

Jari Lavonen

jari.lavonen@helsinki.fi

1 Faculty of Educational Sciences, University of Helsinki, P.O. box 9, FI-00014 Helsinki, Finland

2 Viikki Teacher Training School, University of Helsinki, P.O. box 30, FI-00014 Helsinki, Finland

3 Department of Childhood Education and Centre for Education Practice Research, University of Johannesburg, Soweto Campus, Soweto, South Africa 
Teacher talk in the classroom can be either dialogic or non-dialogic (authoritative) (Scott, Mortimer, \& Aguiar, 2006). Dialogic talk acknowledges multiple voices in the classroom (Matusov, 2009), as teachers ask students their views regarding the topic or phenomenon under discussion (Scott et al., 2006). In addition to discursive turns between teacher and students, even mere teacher talk can be dialogic (Ford \& Wargo, 2012). This kind of dialogic talk can take place, for example, when a teacher reviews students' multiple views on scientific ideas or considers these ideas from different perspectives to illustrate the argumentative nature of science (Bakhtin, 1986; Ford \& Wargo, 2012; Scott et al., 2006). Authoritative talk is the opposite of dialogic talk. It can be understood as teacher-centred knowledge telling, evaluation and the presentation of unquestioned findings.

In science education literature, dialogic talk has appeared to have great educational potential: it can enhance epistemological understanding, argumentation skills and disciplinary core ideas or science practices (Bansal, 2018; Christodoulou \& Osborne, 2014; González-Howard \& McNeill, 2019; Larrain, Howe, \& Freire, 2018; Reznitskaya \& Gregory, 2013). In particular, it can support students' understanding of scientific ideas (Scott et al., 2006). Dialogic teaching focuses on improving students' understanding and raising their engagement by considering their interests and concerns (Calcagni \& Lago, 2018; Matusov, 2009; Scott et al., 2006). However, despite the claim that dialogic teaching has the potential to trigger students' interest, the extant research literature has not addressed this effect. Furthermore, only rarely have students' opinions been sought about dialogic teaching in actual situations. This research aims to fill these gaps in the literature by examining the hypothetical connection between teacher's dialogic talk and students' improved interest in science lessons by applying a simple remote clicker tool as an experience sampling method (ESM).

\section{Theoretical Framework}

\section{Dialogic Teacher Talk in School Science}

Dialogue refers to the acquisition of information from and with others (Bakhtin, 1984; Matusov, 2009). In a classroom context, rather than only presenting specific points of view or initiating question-and-answer routines to check whether the students have the correct answers, a teacher employing a dialogic approach acknowledges multiple voices and students' views. If information-seeking questions are asked, it is done not in order to evaluate students' knowledge but rather to acknowledge and incorporate students' different views. This is especially important because students seldom understand scientific ideas unequivocally, and they may hold incorrect preconceptions about the topic at hand. It is also possible that the teacher does not correctly understand the students' views. If the students experience the discussion atmosphere as nonjudgemental, they may feel free to bring their preconceptions into consideration, and the teacher gets the possibility to redirect their thinking. The teachers' private evaluation of the relevance and quality of students' responses to the teacher's questions may help the teacher revise his or her talk to better communicate the scientific idea. Even a short-term exchange can be dialogic when the teacher asks information-seeking questions. Students then respond in an attempt to solve a shared problem, and the responses 
become collaborative. The value of the dialogic approach can be seen in its power to reveal thinking and meaning-making processes and have them further elaborated on to generate a shared understanding (Scott et al., 2006).

Building on Bakhtin's work, Scott and his colleagues (Scott et al., 2006) developed a communicative approach that emphasises students' views of meaning-making in science learning. The communicative approach is a tool that can be used to evaluate 'whether the students' ideas are taken into account as the lesson proceeds' (Scott et al., 2006, p. 609). The approach consists of two dimensions: discoursive and dialogism. The discoursive dimension determines whether only the teacher is talking or if both the teacher and the students are talking. The dialogism dimension determines whether only an authoritative scientific voice is present or if there are multiple voices. The authoritative voice emphasises curriculum and the teacher's goal of directing students' attention on scientific viewpoints. The two dimensions generate four different qualities of teacher talk (Scott et al., 2006, pp. 611-612), as illustrated in Table 1.

To enlighten the four different qualities of teacher talk, we constructed two imaginary scenarios (A and B), both with two possible follow-ups (A1. Dialogic-Interactive, A2. Non-dialogic-Interactive, B3. Dialogic-Non-interactive, and B4. Non-dialogicNon-interactive). Keeping in mind Mehan's (1979) classical example, where the speaker asks, 'What time is it, Denise?', we constructed scenario A with possible follow-ups A1 and A2 in order to illustrate the distinction between interactive nondialogic and interactive dialogic teacher talk (Table 2). Furthermore, following the idea of dialogic framing (Ford \& Wargo, 2012), we constructed scenario B with possible follow-ups B3 and B4 to illustrate the distinction between non-interactive dialogic talk and non-interactive non-dialogic talk.

In follow-up scenario A1 (Dialogic-Interactive) of sequence A, due to forgotten eyeglasses, the teacher is unable to see the thermometer and needs the information but is not evaluating the answer. In follow-up scenario A2 (Non-dialogic-Interactive) of sequence A, the teacher asks a question, and her response, 'very good, correct', implies that she evaluates whether the student knows how to read the thermometer or not. The follow-up scenario B3 (Dialogic-Non-interactive) of sequence B illustrates multiple voices in teacher talk (c.f. Scott et al., 2006), whereas in follow-up scenario B4 (Nondialogic-Non-interactive), it is the official science voice that can be heard in the teacher's utterance.

Table 1 Four kinds of teacher talk in the communicative approach

\begin{tabular}{llll}
\hline & \multicolumn{1}{c}{ Dialogism } & \\
\cline { 2 - 3 } & Dialogic talk & Non-dialogic talk \\
\hline Discoursive Interactive & $\begin{array}{l}\text { (A1) Dialogic-Interactive: } \\
\text { A range of ideas are welcome }\end{array}$ & $\begin{array}{l}\text { (A2) Non-dialogic-Interactive: } \\
\text { Question-and-answer routine; } \\
\text { answers evaluated }\end{array}$ \\
& $\begin{array}{l}\text { Non-interactive } \\
\text { (B3) Dialogic-Non-interactive: } \\
\text { points of view }\end{array}$ & $\begin{array}{l}\text { (B) Non-dialogic-Non-interactive: } \\
\text { view }\end{array}$ \\
\hline
\end{tabular}


Table 2 Imaginary scenarios illustrating the distinction between interactive non-dialogic and interactive dialogic teacher talk

\begin{tabular}{|c|c|c|}
\hline & Dialogic talk & Non-dialogic talk \\
\hline $\begin{array}{l}\text { Interactive (Example } \\
\text { scenario A: Teacher has a } \\
\text { jar and thermometer in it) }\end{array}$ & $\begin{array}{l}\text { (A1) Dialogic-Interactive: } \\
\text { Teacher: What is the temperature, } \\
\text { Denise? } \\
\text { Student: Twenty-one degrees. } \\
\text { Teacher: Thank you, Denise. }\end{array}$ & $\begin{array}{l}\text { (A2) Non-Dialogic-Interactive: } \\
\text { Teacher: What is the temperature, } \\
\text { Denise? } \\
\text { Student: Twenty-one degrees. } \\
\text { Teacher: Very good; correct, Denise. }\end{array}$ \\
\hline $\begin{array}{l}\text { Non-interactive (Example } \\
\text { scenario B: At the end of } \\
\text { the electromagnetism } \\
\text { class) }\end{array}$ & $\begin{array}{l}\text { (B3) Dialogic-Non-interactive: } \\
\text { Teacher: An inductive loop recognises } \\
\text { big metal objects, such as cars. } \\
\text { Thus, when a car stops at a traffic } \\
\text { light, it can cause the traffic light to } \\
\text { change colour. In addition to cars, } \\
\text { in a previous class, Denise told us } \\
\text { that she found that the traffic light } \\
\text { also changed while she was riding } \\
\text { her bicycle. }\end{array}$ & $\begin{array}{l}\text { (B4) Non-dialogic-Non-interactive: } \\
\text { Teacher: At an intersection, an } \\
\text { inductive loop detector recognises a } \\
\text { car, and the traffic light colour } \\
\text { changes. }\end{array}$ \\
\hline
\end{tabular}

Scott et al. (2006), and particularly Ford and Wargo (2012), emphasise that teacher talk can be dialogic not only between different people who have different views (Matusov, 2009) but also between scientific ideas, with only one person speaking about them. According to Scott et al. (2006), one-person talk is dialogic when the speaker is comparing, revisiting and summarising different viewpoints. Scientific ideas are argumentative by nature (Ford \& Wargo, 2012), and in the context of science teaching, mere teacher talk can be dialogic if the teacher (1) uses scientific ideas to explain natural phenomena, (2) uses multiple ideas and evaluates competing ideas, or (3) demonstrates the explanatory power of higher order ideas such as a connected series of concepts or principles. Although dialogic teaching is beneficial for learning, it is seldom used in science classrooms (Larrain et al., 2018; Lehesvuori, Viiri, RaskuPuttonen, Moate, \& Helaakoski, 2013; Mercer, Dawes, \& Staarman, 2009; Pimentel \& McNeill, 2013).

\section{Interest}

Interest plays an undeniable role in motivation and learning (Silvia, 2008). According to Ainley and Hidi (2014), interest motivates exploration and information seeking. Hidi and Renninger (2006) and Renninger and Hidi (2016) distinguish between short-term situational interest and longer term individual interest. Situational interest is aroused and directed as a function of the 'interestingness' of a situation (Schraw \& Lehman, 2001). Interest development follows a four-phase path: Situational interest is first triggered and then maintained; next, it evolves into an emerging individual interest, and then, finally, into a well-developed individual interest (Hidi \& Renninger, 2006; Renninger \& Hidi, 2016). Students' experiences of the interestingness of the situation differ based on where they are on the continuum of interest development. Triggering situational interest is partially under the control of teachers, who can attempt to spark interest by organising stimulating discussions, learning environments and activities. In 
this research, we understand a 'situation' as a 'relative position or combination of circumstances at a certain moment' (Situation, n.d.).

Novel, complex, comprehensible and personally relevant teaching material may arouse situational interest (Hidi \& Renninger, 2006; Silvia, 2008). In the context of science teaching, Palmer (2009) adds that the feeling of choice, experienced physical activity, and social involvement can also have an effect on situational interest. According to Hidi and Renninger (2006), if students experience a lesson's content or task as meaningful or as allowing personal involvement, they may focus their attention on it for an extended period of time, thus leading to the emergence of maintained situational interest. Rotgans and Schmidt (2017) demonstrated in their study that the growth of individual interest over time can be ascribed to the repeated arousal of situational interest caused by the problems presented to students. Dialogic teacher talk may communicate the topic as complex, controversial and even conflicting. Based on these ideas, we argue that the dialogical approach has the potential to support the emergence of interest.

\section{Research Question}

Dialogic teacher talk can build on students' interests and concerns and can encourage students to seek more knowledge (Calcagni \& Lago, 2018; Hidi \& Renninger, 2006; Krapp, 2002; Matusov, 2009; Mehan, 1979; Scott et al., 2006). Based on the literature, we assumed that students find dialogic teacher talk situations more interesting than non-dialogic teacher talk situations. Therefore, the research question was formulated as follows: Is there a difference between students' interest in dialogic teacher talk situations and non-dialogic teacher talk situations?

\section{Methodology}

This study employed a mixed-method approach. The ESM was used to measure students' situational interest. In more detail, students were frequently asked to express their interest by using the Boxlight MimioVote remote clicker system (Boxlight Corporation, Belfast, Northern Ireland; https://global.boxlight.com/mimiovoteformative-assessment-tool/). In addition, video observations were used to classify teacher talk as dialogic or non-dialogic in sampled situations. Finally, we analysed whether there is a connection between teacher's dialogic talk and students' interest by combining the video analyses and the ESM.

\section{Participants and Informed Consent}

In the first phase of the research, an invitation to participate in the study was sent to several physics and chemistry teachers who had previously participated in university projects. Three female and three male middle school teachers decided to participate in this research. The participating teachers worked in three schools located in the Helsinki region. Participating teachers had at least a master's degree in the teaching subject, while one teacher had a PhD in chemistry. Two of the schools were located in relatively high socio-economic areas. In these schools, very few, if any, students had an 
immigrant background or Finnish as a second language. The third school was located in an area with a more diverse student background. The teacher with a $\mathrm{PhD}$ in chemistry taught in this school. Table 3 describes the classes being taught in grades 8 or 9 , when students are typically 14 to 15 years old.

Permission and willingness to participate were requested from the school administration, the principal, the teacher, the parents and the students themselves, according to the modus operandi of each school. The informed consent principle was employed, and participation in the research was voluntary. Altogether, 43 female and 44 male students enrolled in the research and answered the interest queries in at least 1 of the 3 lessons.

The lessons were planned according to the Finnish National Core Curriculum for Basic Education (Opetushallitus, 2004) and focused on physics or chemistry topics, such as alkalinity, electricity and magnetism, heat and temperature and motion and force. A wide variety of teaching methods were employed, including teacher lecturing, demonstrations, small group hands-on activities with laboratory equipment, data logging with computers, teacher-led discussions, note taking and paper-and-pencil problems.

Each teacher agreed to teach three lessons in the study. In order to ensure variation in the interest levels of the students in different situations, teachers were asked to include something they believed students would find interesting in the second lesson. However, the study was planned and organised to interfere with ordinary teaching as little as possible. In the informal discussions held after the data gathering, the teachers mentioned that the lessons included in the study were quite similar to their usual lessons.

\section{Data Gathering}

The interest level of a person can be examined during an activity or afterwards, but it can be difficult for a participant to retrospectively evaluate their interest levels in a certain past situation and restore their emotional state of mind. However, the memory bias is diminished if the experiences are collected during the activity. The ESM is a reliable means designed for tracking an individual's experience at certain moments in

Table 3 Description of classes participating in the research

\begin{tabular}{|c|c|c|c|}
\hline $\begin{array}{l}\text { Teacher number } \\
\text { (gender) }\end{array}$ & Grade topic & $\begin{array}{l}\text { Number of students } \\
\text { in class }\end{array}$ & $\begin{array}{l}\text { Total number of participating } \\
\text { students (number of girls) }\end{array}$ \\
\hline \#1 (male) & $\begin{array}{l}\text { 8th grade } \\
\text { Heat transfer }\end{array}$ & 16 & $14(5)$ \\
\hline \#2 (female) & $\begin{array}{l}\text { 9th grade } \\
\text { Friction, air resistance }\end{array}$ & 16 & $13(5)$ \\
\hline \#3 (male) & $\begin{array}{l}\text { 9th grade } \\
\text { Alkalinity }\end{array}$ & 16 & $13(9)$ \\
\hline \#4 (female) & $\begin{array}{l}\text { 8th grade } \\
\text { Heat expansion }\end{array}$ & 19 & $19(5)$ \\
\hline \#5 (male) & $\begin{array}{l}\text { 9th grade } \\
\text { Electromagnetism }\end{array}$ & 16 & $14(10)$ \\
\hline \#6 (female) & $\begin{array}{l}\text { 8th grade } \\
\text { Heat transfer }\end{array}$ & 16 & $8(6)$ \\
\hline
\end{tabular}


time that involves repeatedly collecting responses to questions tailored to fit the particular situation (Hektner, Schmidt, \& Csikszentmihalyi, 2007). After hearing a signal at random moments in time, participants answer questions about their experiences at that particular moment (e.g. Csikszentmihalyi \& Hunter, 2003). The ESM can be conducted through employing paper-and-pencil tools (e.g. Palmer, 2009) or by using digital tools designed for mobile devices (Katz-Buonincontro \& Hektner, 2014; Litmanen, Lonka, Inkinen, Lipponen, \& Hakkarainen, 2012). Through employing the ESM, it is possible to separate the immediate context of a certain experience from more long-term conditions (Csikszentmihalyi \& Hunter, 2003). In this research, we used the Boxlight MimioVote assessment system handset for experience sampling (Boxlight Corporation, Belfast, Northern Ireland).

At the beginning of the first lesson, the students were informed about the research and offered an opportunity to ask further questions about the study. Following the introduction, each student was given a MimioVote assessment system handset. The experience sampling request was to 'evaluate the interestingness of the situation' (c.f. Schraw \& Lehman, 2001). We applied the one-question-measurement method as outlined in Palmer (2009), where the scale of ' $\mathrm{A}=$ very boring to $\mathrm{E}=$ very interesting' was written on the blackboard, and students were told that the scale was a continuum between the extremities of A and E. The options between A and E were not named. Students were instructed that when the lights on the clicker lit up, they were to express their interest at that moment.

After 15 to $25 \mathrm{~min}$, the science lesson and the video recording started. There were two video cameras in the classroom, both focused on the students and located in the front of the class. The cameras captured both the teacher's and students' voices, but in this study, we were interested only in the situations in which the teacher talked with or to the whole group of students. The second and third lessons were recorded in their entirety.

The experience sampling was synchronised by using remote clickers so that all students were asked to respond at the same time. Once the activity or situation changed or the same activity had lasted $10 \mathrm{~min}$, the first author remotely turned on the lights of the students' handsets to indicate that students should respond. There were a variety of situations in which the students were asked to respond, including different forms of teacher talk. The handsets were numbered, and the researcher saw from his laptop screen when the individual students had answered. Students who did not respond after $1 \mathrm{~min}$ were asked by the researcher again to respond. After about $2 \mathrm{~min}$, as well as when the activity or situation in the classroom changed, the opportunity to respond ended. The reason for this was to guarantee the possibility of connecting the students' expressed interest levels with the video-observed classroom situation.

\section{Data Handling}

There were 158 situations in which the students were asked to express their interest. A classroom situation was selected as the analysis unit. The classification of classroom situations started by synchronising students' clicker responses and video recordings. This was done by examining the log document written during the lessons and from the video, as it was possible to notice when clicker lights lit up. Authors 1 and 2 went through the lesson recordings, and in the first phase, situations for further analysis were 
selected. Altogether, 65 situations were excluded from the analysis because, in those situations, the teacher talk focused on classroom management or the students were doing either independent work or small group activities. Only those situations in which the teacher was talking with or to the whole class were included in the analysis. The first and second author watched each situation together, and the recordings started at about 2 min before the students were asked to respond. When classifying the situations, authors 1 and 2 negotiated the decision based on the characteristics of dialogic talk as long as a consensus was reached. Appendix 1 presents illustrative examples of the classroom situations and explanations as to why a situation was classified as dialogic or non-dialogic. Ultimately, 93 situations were classified in this manner.

In order to analyse whether there was a difference between students' interest in dialogic talk and non-dialogic talk situations, two values were calculated: (1) the individual mean interest score in dialogic talk situations, and (2) the individual mean interest score in non-dialogic talk situations. We applied a related samples Wilcoxon signed rank test, which is a non-parametric equivalent for the paired sample $t$ test, to evaluate whether students found dialogic talk situations more interesting than nondialogic situations.

\section{Results and Discussion}

In the analyses, 21 situations were classified as dialogic and 72 as non-dialogic. Two of the teachers had only one dialogic moment in their teaching. At the other extreme, there was one teacher whose talk was classified as dialogic in nine situations. On average, there were 3.5 dialogic talk situations and 12 non-dialogic talk situations per teacher (Table 4). This finding is consistent with the findings of Lehesvuori et al. (2013) and Hiltunen, Kärkkäinen, and Keinonen (2019), who argued that dialogic talk is used only occasionally.

On a scale A to $\mathrm{E}$ (coded 1 to 5), the median value of individual interest means for non-dialogic situations was 3.3 (number of students $N=87$ ), and for dialogic situations, the median value of individual interest means was 3.5 (number of students $N=$ 85 ). Thus, there were two students who were not responding at the situations classified as dialogic. Because the middle point of the scale was 3.0, we interpreted that a mean score of over 3.0 meant that respondents experienced the analysed science teaching situation as neutral or slightly interesting. The related samples Wilcoxon signed rank

Table 4 Number of dialogic and non-dialogic talk situations

\begin{tabular}{lll}
\hline Teacher number & Number of dialogic talk situations & Number of non-dialogic talk situations \\
\hline$\# 1$ & 9 & 5 \\
$\# 2$ & 3 & 12 \\
$\# 3$ & 1 & 18 \\
$\# 4$ & 5 & 11 \\
$\# 5$ & 2 & 17 \\
$\# 6$ & 1 & 9 \\
\hline
\end{tabular}


test revealed that students rated dialogic teacher talk situations statistically more interesting than non-dialogic teacher talk situations $(Z=-2.62 ; p<0.05)$.

Previous research highlighted that although dialogic teaching is beneficial from the point of view of science learning (Reznitskaya \& Gregory, 2013; Scott et al., 2006), it is not commonly used (Howe \& Abedin, 2013). Our results indicate that dialogic teacher talk is associated with higher interest levels. This study contributes to the field of science education research by revealing that dialogic talk may trigger or support students' interest. In summary, dialogic teaching takes into account students' interest and concerns (Calcagni \& Lago, 2018; Matusov, 2009; Scott et al., 2006), involves students personally in the situation (Hidi \& Renninger, 2006; Renninger \& Hidi, 2016), and presents content in a more complex manner (Silvia, 2008).

\section{Limitations}

Before we discuss the implications of this study, we should identify its limitations. They include sample selection, ESM synchronisation and the analysed classroom situations. First, because the teachers were selected according to their willingness to participate in the study, the students were not randomly selected. Random participant recruitment for a science education research project may complicate the research since randomly selected teachers may not have a positive attitude towards the research activities. The collection of research data in authentic situations always interferes with classroom activities to some extent, and the teachers need to be willing to take this interference into account when planning their lessons. Furthermore, we were aiming not to generalise the results to any student population but, rather, to test hypotheses about the connection between dialogic teaching and students' interest in different situations. Therefore, the teachers' commitment to the research helped ensure a more authentic view of science teaching.

The second limitation is related to ESM synchronisation. Before evaluating the interestingness of the science classroom situation, students had the opportunity to complete their current task. Hence, they were not necessarily responding at exactly the same time. This decision was made while the research was being planned with the teachers, who emphasised the importance of diminishing the possible distraction of engagement while responding and requested that the students have an opportunity to finish their current activity before responding. Therefore, it is possible that in some responses, the student evaluated a different situation than the one analysed in the video recording. However, the possibility to respond ended when the classroom situation changed, an aspect that may have improved the validity of the research regardless of the increasing missing data. The analyses showed a statistically significant difference in interest between dialogic teacher talk and non-dialogic teacher talk situations despite the possible methodological 'noise' in the data that this approach may have produced.

We understand that it is impossible to know what students were really thinking about when they were asked to evaluate the interestingness of the classroom situation using a remote clicker. It is possible that a student's attention had been somewhere other than on the intended learning activity. Moreover, the previous situation may have influenced the students' perception in the present situation. Using a five-button clicker, it was possible to ask for students' evaluation of only 
one aspect of the classroom situation, in this case, the interestingness of the situation. Despite this limitation, the instrument used minimised the time to respond and the expected cognitive load related to the measurements. We argue that it interfered with the teaching and learning as little as possible. Using clickers also diminished the degree of memory bias when compared with asking students their opinions retrospectively.

\section{Conclusions}

In dialogic talk, the teacher helps students to compare, juxtapose and argue their ideas (c.f. Scott et al., 2006). Teachers do not just offer one correct answer; rather, they challenge students with different perspectives and supporting arguments. This approach may be confusing for the students at first if they are used to more authoritative teacher talk. Changing the perspective requires effort, and it may not be easy for adolescents to admit that there may be different viewpoints regarding a phenomenon and that their viewpoints may even differ from each other considerably.

Employing dialogic talk may also be demanding for the teacher because it requires listening to the students' perspectives and taking into account their thoughts while directing the teaching situation, which means space must be left for the improvisatory aspects of teaching instead of following a ready-made script (Sawyer, 2004). Students are sensitive to teacher talk, and although the teacher does not use a clear initiation-response-evaluation sequence in the classroom, students may interpret hesitation or a break in teacher talk as denial (Mehan, 1979) Therefore, it is important that the teacher explicitly demonstrates his or her interest in hearing students' ideas.

Due to its several limitations, this research should be considered a preliminary single case study. From a methodological point of view, we recommend interrupting the lesson while students are signalled to respond to an ESM questionnaire. Further, we noticed that some students did not recognise the lights as a signal. Therefore, a sound signal might help students to respond; this would also help to more accurately connect the situation and the students' responses. However, teachers may find sound signals to be too much interference with the lesson, which therefore risks less authentic talk in the lesson. In our study, even though there were statistically significant differences between students' interest in dialogic and non-dialogic teacher talk situations, the sample was rather small and there is a need for studies with greater numbers of students and classes. Despite the preliminary nature of the study, the research has nonetheless shown that interest in dialogic teacher talk situations is likely higher than interest in non-dialogic teacher talk situations. It is known that dialogic talk is rare (Lehesvuori et al., 2013), but change towards more dialogic forms of classroom talk is possible (Rees \& Roth, 2019). Therefore, this paper provides additional support for teachers to emphasise dialogic teaching because it may develop student interest in science lessons.

Funding Information Open access funding provided by University of Helsinki including Helsinki University Central Hospital. 


\section{Appendix}

\section{Appendix 1. Examples of situations assessed in the study}

\section{Dialogic situations}

\section{Situation 1.1.2}

Teacher involves the comparison of a student-generated graph and a standard graph The teacher encouraged the students to interpret and think about their findings. The task was to prepare a temperature versus time graph taken from a heat transfer experiment. One student developed a different graph than the one presented in the document camera. The teacher encouraged the student to interpret the graph and seek a possible interpretation for the difference by elaborating on the measurement process.

1. Student: Does it matter if they are close? The difference is not seen very well here [the student refers to their own graph] — it does not look very clear.

2. Teacher: Well, the heat transfer is the most effective there. If you cut here, the temperature difference is small, so it is not very clear.

3. Student: Our water was not very hot.

4. Teacher: Then, the scales in the axis also influence whether it is large compared to ...

5. Student: We had ten, I mean, two-minute intervals, the measurement about.

6. Teacher: Here, one square is 20 seconds, so three squares are one minute.

7. Student: I have half ... well.

8. Teacher: It is also important to interpret the graph-why did you conclude that there was heat loss?

9. Student: Because bag number two can't warm up.

10. Teacher: Interesting observation.

11. Student: And here, there has to be a measurement error, because this rises this way. [The student brings the workbook up to the document camera.]

12. Teacher: What might have happened if your graph looked like this? Is it different from the previous one?

13. Student: We assume that there was heat loss, or it heated there, if the heat did not get out of the jar and the thermometer's reach.

14. Teacher: Yes, well, I wonder what kind of experiment setting we had and what we have done ...

15. Student: We put two bags, one with hot [water] and another with colder [water] in jars next to each other, and they were expected to have the same temperature in the end.

16. Teacher: Yes, measured ...

17. Student: They were expected to interact with each other.

18. Teacher: Yes, there were thermometers. What I think is that if there was cold [water], then the initial temperature was ...

\section{Situation 1.1.7}

Teacher involves the temperature readings in warm or hot water in black and foilcovered jars over time. Students shared their findings and results of scientific inquiry activities. This excerpt from the lesson shows that the teacher allowed space for 
students to present their different findings and results from the experiment. In the experiment, students followed the cooling of the water in different jars. The expected finding was that the water in the black jar cooled in the shortest period of time. However, the teachers accepted various findings from the students, even when they were clearly odd, as statements 5, 12, 15, and 17 illustrate.

1. Teacher: The black jar cools faster than the bright jar. Is this our conclusion? Did anyone have colder water in the black jars?

2. Student: We found that this [aluminium] foil jar and both had cold water, and in the foil jar, the temperature rose faster.

3. Teacher: Well ...

4. Student: I do not know whether it is right; it increased by only two degrees.

5. Teacher: Still, it was your result-you compared the foil and the black jars, and the foil jar warmed faster?

6. Student: Yes.

7. Teacher: Yes, interesting, and quite right.

8. Student: We have a similar [setting], and there were no differences; we had the same [temperature] the whole time.

9. Teacher: So, there were no big differences between the black and the foil jars?

10. Student: We did not note any differences.

11. Student: The black jar should cool the fastest.

12. Teacher: Fascinating issue ... [a phone is ringing] ... whose phone is that?

13. Teacher: We should think about our experiment setting. Is it possible that there is thermal transformation from the bottom? Well, the black jar cools faster than the bright jars, and accordingly, the black jar should warm faster than the bright jar does.

14. Student: We had ... [says something very quietly].

15. Teacher: Interesting results. Can we draw any conclusions?

16. Student: We can say that there was something wrong in our experimental settings because we all got different results.

17. Teacher: Good point. We are able to make this kind of observation.

Situation 1.3.1

The teacher introduced the complex phenomenon of the atmosphere as a topic, without providing a clear or ready explanation. This situation can be interpreted as illustrating the teacher's attitude that scientific ideas are proposals that are open to critique and improvement. The teacher emphasised in statement 5 that there was no clear answer, only proposals, to the issue raised in the discussion.

1. Teacher: [The students enter the class and take their seats.] Very well. We have had very interesting times with the weather. I observed that during the night, the temperature fell to minus ten degrees [Celsius], yet during the day, it is relatively warm.

2. Student: Isn't it going to be minus ten next weekend?

3. Teacher: Yes. It was in the forecast that the weekend will be chilly. [One student comes late into the class.] It is interesting, this thermal phenomenon, as such. When 
there are clouds, it could be much warmer, and when it is bright, the temperature can go up.

4. Student: It seems very odd.

5. Teacher: It is a quite exciting phenomenon. We can ponder it during the course. There is no clear answer.

\section{Situation 1.3.6}

The teacher showed different graphical representations of changes in states and drew a figure on the blackboard; the students copied the figure into their notebooks. The teacher emphasised that 'for me, this kind of figure is clearer than the figure in the textbook. I wanted to give a different view, in addition to the textbook'. Thus, there were multiple voices present in the classroom.

Situation 4.2.3

The teacher's responses to the students' proposals showed that the teacher was not evaluating their ideas. The teacher first asked a question with a known answer, but she corrected herself and wondered aloud whether the students would be able to guess the name of the apparatus. By saying she had never tried the apparatus, she could not evaluate the students' proposals because she did not know the answer. Teacher talks made it clear to the students that there was no ready solution, so a diversity of ideas were welcome.

1. Teacher: Well, let's start the lesson. Please come closer to see the equipment I found in the warehouse. Take the clickers with you. Come closer to see-otherwise, you will not see anything. I would like to show you this apparatus. [Students put on goggles and go closer.] See ... Peter and Tom, would you come to see? This is a very large metal instrument. I can hardly lift it. Do you know what the name of it is? Well, you cannot know. This is a bolt breaker. I have never tried it, and now, we should try to break these kinds of bolts. One teacher in the school has tested it, and he managed to [break] this kind of bolt. Now, we should think together: how in the world can one break bolts using this gadget? Try these bolts - these are quite robust pieces of metal. How can one break bolts using this apparatus ... any ideas?

\section{Situation 5.3.2}

The teacher refers to another person's experience. The teacher does not deny the student's perception even though he contradicts it. Instead, he introduces possible explanations as to why there are different perceptions.

1. Teacher: Well, let's start this lesson's new topic. We should go further towards understanding the connection between electricity and magnetism. You should be able to answer this kind of question. We visited an electricity power plant, and then we started to understand what we saw and how they generate electricity there. I mentioned that the visit was at a rather strange time. And then the metal detectors. Have you noticed that certain traffic lights change when you approach by car? But, if you walk, they do not change-only when you approach by car. 
2. Student: They also change by bicycle.

3. Teacher: Oh, it works with bicycle, also! It is good that you had this kind of experience.

4. Student: Yesterday, someone in another class said that they do not work if you ride a moped. If you have cycled in the middle of the street, you will understand how it [a motion sensor in a traffic light] works.

\section{Non-dialogic situations}

\section{Situation 3.3.9}

In this situation, there is a question-and-answer routine in which the teacher asks questions, the students respond and the teacher evaluates the answers.

1. Teacher: Ionic compound, salt. Let's take an example [waits]. No example. I write here sodium carbonate. It is a good example. N-A two C-O three. This is sodium carbonate. Do you know what it is, this sodium carbonate? [The teacher waits, and no one wants to answer.] There is chemistry everywhere! Everything is chemistry! In the kitchen, there is a lot of chemistry. This is in the kitchen.

2. Student: Soda.

3. Teacher: Baking soda or baking powder, yes! There is one thing more we will write concerning ionic compounds. We had two kinds of ionic compounds in our experiment. [Earlier, the students had conducted a precipitation experiment using several acids and bases.] We could classify them. This is in relation to their appearance in water.

4. Student: [The student gives an answer that cannot be heard.]

5. Teacher: Yes! It is said that there are poorly soluble and soluble salts. The precipitation formed is poorly soluble salts, and soluble salts are ionics formed in aqueous solutions. Let's write that not all salts are water soluble. Last line: poorly soluble salts are possibly formed by precipitation reactions. Let's say ... Is table salt a poorly soluble or soluble salt? [No one wants to answer; the response system beeps.] It is soluble. It is spectacularly soluble. It is possible to put an enormous amount-well, there is a limit ... Still, it is very soluble in water. These [substances in the experiment] are different than what you had in the experiment tubes.

\section{Situation 4.1.7}

The teacher instructs a student in using a data logging tool in front of the class. Student is asked to be an assistant.

1. Teacher: Okay, hey, now we can get back to our measurement? Who wants to come and help a little bit? [One student comes voluntarily to use the teacher's computer; some students applaud.]

2. Teacher: Switch to LoggerPro, and let's see [measurement plot seen in the screen] whose prediction this was. We could analyse a little. Please move the cursor to the middle . . . We'll see the temperature. There is it ... thirty $\left[{ }^{\circ} \mathrm{C}\right]$, thirty-two, thirtyfour. So, we see it is thirty-three and a half, about. Well, here is something quite interesting. How can we find out the middle point of the temperature curve?

3. Student: We sum them. 
4. Teacher: Yes. Could you please show the starting point of the blue curve, and who wants to come and write it on the blackboard? Everet, please come. [The student response system beeps.] Rob, please say the number. Is it forty-five? It is not exactly there [the teacher gives instructions to the student using the computer] forty-six. Could you put the Celsius degree, also? It is an easy calculation. The lower number is twenty-four. Could you please calculate the mean? It looks unusual, the temperature degrees. What's wrong?

Open Access This article is distributed under the terms of the Creative Commons Attribution 4.0 International License (http://creativecommons.org/licenses/by/4.0/), which permits unrestricted use, distribution, and reproduction in any medium, provided you give appropriate credit to the original author(s) and the source, provide a link to the Creative Commons license, and indicate if changes were made.

\section{References}

Ainley, M., \& Hidi, S. (2014). Interest and enjoyment. In R. Pekrun \& L. Linnenbrink-Garcia (Eds.), International handbook of emotions in education (pp. 205-227). NY: Routledge.

Bakhtin, M. (1984). Problems of Dostoevsky's poetics: Theory and history of literature, volume 8 (C. Emerson, Ed. \& Trans. Minneapolis: University of Minnesota Press.

Bakhtin, M. M. (1986). Speech genres and other late essays (C. Emerson \& M. Holquist, Eds., V. W. McGee, Trans.). Austin, TX: University of Texas Press.

Bansal, G. (2018). Teacher discursive moves: Conceptualising a schema of dialogic discourse in science classrooms. International Journal of Science Education, 40, 1891-1912. https://doi.org/10.1080 /09500693.2018.1514543.

Calcagni, E., \& Lago, L. (2018). The three domains for dialogue: A framework for analysing dialogic approaches to teaching and learning. Learning, Culture and Social Interaction, 18, 1-12. https://doi. org/10.1016/j.lcsi.2018.03.001.

Christodoulou, A., \& Osborne, J. (2014). The science classroom as a site of epistemic talk: A case study of a teacher's attempts to teach science based on argument. Journal of Research in Science Teaching, 51, 1275-1300. https://doi.org/10.1002/tea.21166.

Csikszentmihalyi, M., \& Hunter, J. (2003). Happiness in everyday life: The uses of experience sampling. Journal of Happiness Studies, 4(2), 185-199. https://doi.org/10.1023/A:1024409732742.

Ford, M. J., \& Wargo, B. M. (2012). Dialogic framing of scientific content for conceptual and epistemic understanding. Science Education, 96(3), 369-391. https://doi.org/10.1002/sce.20482.

González-Howard, M., \& McNeill, K. L. (2019). Teachers' framing of argumentation goals: Working together to develop individual versus communal understanding. Journal of Research in Science Teaching, 56, 821-844. https://doi.org/10.1002/tea.21530.

Hektner, J. M., Schmidt, J. A., \& Csikszentmihalyi, M. (2007). Experience sampling method: Measuring the quality of everyday life. Thousand Oaks: Sage.

Hidi, S., \& Renninger, K. A. (2006). The four-phase model of interest development. Educational Psychologist, 41(2), 111-127. https://doi.org/10.1207/s15326985ep4102_4.

Hiltunen, M., Kärkkäinen, S., \& Keinonen, T. (2019). Biology student teachers' dialogic talk in inquiry-based instruction. Journal of Biological Education, 1-15. https://doi.org/10.1080/00219266.2019.1575264.

Howe, C., \& Abedin, M. (2013). Classroom dialogue: A systematic review across four decades of research. Cambridge Journal of Education, 43(3), 325-356. https://doi.org/10.1080/0305764X.2013.786024.

Katz-Buonincontro, J., \& Hektner, J. M. (2014). Using experience sampling methodology to understand how educational leadership students solve problems on the fly. Journal of Educational Administration, 52(3), 379-403. https://doi.org/10.1108/JEA-12-2012-0135.

Krapp, A. (2002). An educational-psychological theory of interest and its relation to SDT. In E. L. Deci \& R. M. Ryan (Eds.), Handbook of self-determination research (pp. 405-430). Rochester: Boydell \& Brewer.

Larrain, A., Howe, C., \& Freire, P. (2018). 'More is not necessarily better': Curriculum materials support the impact of classroom argumentative dialogue in science teaching on content knowledge. Research in Science \& Technological Education, 36(3), 282-301. https://doi.org/10.1080/02635143.2017.1408581.

Lehesvuori, S., Viiri, J., Rasku-Puttonen, H., Moate, J., \& Helaakoski, J. (2013). Visualizing communication structures in science classrooms: Tracing cumulativity in teacher-led whole class discussions. Journal of Research in Science Teaching, 50(8), 912-939. https://doi.org/10.1002/tea.21100. 
Litmanen, T., Lonka, K., Inkinen, M., Lipponen, L., \& Hakkarainen, K. (2012). Capturing teacher students' emotional experiences in context: Does inquiry-based learning make a difference? Instructional Science, 40(6), 1083-1101.

Matusov, E. (2009). Journey into dialogic pedagogy. New York: Nova Science Publishers.

Mehan, H. (1979). "What time is it, Denise?": Asking known information questions in classroom discourse. Theory Into Practice, 18(4), 285-294.

Mercer, N., Dawes, L., \& Staarman, J. K. (2009). Dialogic teaching in the primary science classroom. Language and Education, 23(4), 353-369. https://doi.org/10.1080/09500780902954273.

Opetushallitus. (2004). National core curriculum for basic education 2004: National core curriculum for basic education intended for pupils in compulsory education. Helsinki: National Board of Education.

Palmer, D. H. (2009). Student interest generated during an inquiry skills lesson. Journal of Research in Science Teaching, 46(2), 147-165. https://doi.org/10.1002/tea.20263.

Pimentel, D. S., \& McNeill, K. L. (2013). Conducting talk in secondary science classrooms: Investigating instructional moves and teachers' beliefs. Science Education, 97(3), 367-394. https://doi.org/10.1002 /sce.21061.

Rees, C. A. B., \& Roth, W.-M. (2019). Discourse forms in a classroom transitioning to student-centred scientific inquiry through co-teaching. International Journal of Science Education, 41(5), 586-606. https://doi.org/10.1080/09500693.2019.1571649.

Renninger, K. A., \& Hidi, S. (2016). The power of interest for motivation and engagement. New York: Routledge.

Reznitskaya, A., \& Gregory, M. (2013). Student thought and classroom language: Examining the mechanisms of change in dialogic teaching. Educational Psychologist, 48(2), 114-133. https://doi.org/10.1080 /00461520.2013.775898.

Rotgans, J. I., \& Schmidt, H. G. (2017). Interest development: Arousing situational interest affects the growth trajectory of individual interest. Contemporary Educational Psychology, 49, 175-184. https://doi. org/10.1016/j.cedpsych.2017.02.003.

Sawyer, R. K. (2004). Creative teaching: Collaborative discussion as disciplined improvisation. Educational Researcher, 33(2), 12-20. https://doi.org/10.3102/0013189x033002012.

Schraw, G., \& Lehman, S. (2001). Situational interest: A review of the literature and directions for future research. Educational Psychology Review, 13(1), 23-52. https://doi.org/10.1023/A:1009004801455.

Scott, P. H., Mortimer, E. F., \& Aguiar, O. G. (2006). The tension between authoritative and dialogic discourse: A fundamental characteristic of meaning making interactions in high school science lessons. Science Education, 90, 605-631. https://doi.org/10.1002/sce.20131.

Silvia, P. J. (2008). Interest-The curious emotion. Current Directions in Psychological Science, 17(1), 57-60. https://doi.org/10.1111/j.1467-8721.2008.00548.x.

Situation. (n.d.). In Merriam-Webster's online dictionary. Retrieved Nov. 15, 2019 from https://www.merriamwebster.com/dictionary/situation. Accessed 15 Nov 2019. 